\title{
水稲種子生産の収穫調製機械化技 術体系に関する研究
}

\section{第 2 報 自脱型コンバインの利用技術 と損傷籾の発生 *}

\author{
岩井昭衛・猪原明成・笠原正行・飯田周治
}

\begin{abstract}
Studies on the Mechanized System of Harvesting and Preparating of Rice Seed Production.

II. Utilization Technique of the Head Feeding Combines and Occurrences of the Damaged Rough Rices.

Syoei IWAI, Akinari INOHARA, Masayuki KASAHARA, Syuzi IIDA ${ }^{+}$
\end{abstract}

\section{1. 緒 言}

稲作の機械化，特に機械移植により密植化および 植付本数の増加に伴って種粐の需要が急激に増加し ているが,てれを生産する農家は種粐としての機能 を低下させないため，現在す手作業を主とした作業 体系で行っている。このため収穫作業は機械化され ておらず，採種農家の維持増大が因難な状況になっ でた。

そこで筆者らは既存の自脱型コンバイン利用によ る採種の機械化収穫調製作業体系の確立をめさし 本報の研究課題に着手した。

自脱型コンバインを利用して種子生産を行ら場合 発芽率に最す影響を及ほす要因は报胴の回転数と収 穫時の粐含水率であるととを報告した。すするわち収
穫時の粐含水率に応じて扱胴回転数を規制すれば， 種粐としての高水分粐を収穫するととがでをる。 本報で岋市販されている5 銘柄の機種別の標準回 転数を基準にして損傷粐の発生程度と発芽能力を比 較検討し,そのとをの作業性能と損傷粐の発生要因 を調査したのでその結果をとりまとめ報告する。

\section{2. 試験材料と方法}

収穫条件の笅しい高水分粐を用い，5機種の自脱 型コンバインを使用し，富山農試ほ場で行った。各 機種の標準回転数を基準にして比較検討し，粐の損 賃と発芽率にどの上うに影響を与えるかについて調 查した。

\section{1) 供試材料}

譏種別による損傷粐の発生程度と発芽率について
第 1 表 作物の概要

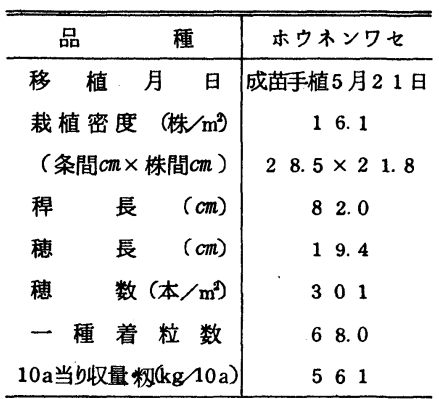

第 2 表 収稪時の供試材料

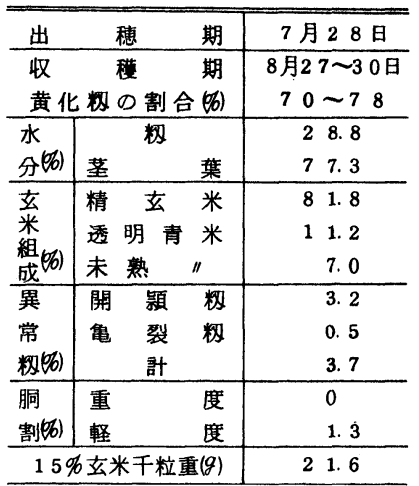

第 3 表 作物の概要

\begin{tabular}{|c|c|}
\hline 品 & 日 本 晴 \\
\hline 移 植 方 法, 月日 & $\begin{array}{l}2 \text { 条田植機 } \\
5 \text { 月 } 14 \text { 日 }\end{array}$ \\
\hline 種 & 8 月 25 日 \\
\hline 稪 & 10 月 $6 \sim 8$ 日 \\
\hline 栽植密度 (株 $\left./ \mathrm{m}^{2}\right)$ & 23.5 \\
\hline 条間 $\mathrm{cm} \times$ 株間 $\mathrm{cm}$ & $31.0 \sim 13.7$ \\
\hline$(\mathrm{cm})$ & 88.7 \\
\hline (cm) & 19.4 \\
\hline 数 $\left(\right.$ 本 $\left./ \mathrm{m}^{2}\right)$ & 456 \\
\hline 一 穂 着 粒 数 & 73.7 \\
\hline $10 \mathrm{a}$ 当b収量 ·粐 $(\mathrm{kg} / 10 \mathrm{a})$ & 658 \\
\hline
\end{tabular}

* 昭和 52 年 5 月 10 日受理

* 富山県農業試験場 富山市吉岡 $11224-1$

+ Toyama Agr. Exp. Station, 1124-1, Yoshioka, Toyama-shi, 930-11. 
第 4 表 供試機種の脱穀部の仕様

\begin{tabular}{|c|c|c|c|c|c|c|c|c|c|c|}
\hline \multirow{2}{*}{ 機 } & \multirow{2}{*}{ 種 } & \multirow{2}{*}{$\begin{array}{c}\text { 扱胴径 } \\
(m m)\end{array}$} & \multirow{2}{*}{$\begin{array}{c}\text { 扱胴 巾 } \\
(\pi \in m)\end{array}$} & \multirow{2}{*}{\multicolumn{2}{|c|}{$\begin{array}{r}\text { 扱茵高さ受網目の } \\
(m m)\end{array}$}} & \multicolumn{4}{|c|}{ 扱歯の種 類 (本) } & \multirow{2}{*}{$\begin{array}{l}\text { 扱胴標準 } \\
\text { 回 転 数 } \\
\text { (イ桩. p.m) }\end{array}$} \\
\hline & & & & & & 整梳歯 & 補強歯 & 並歯 & 計 & \\
\hline $\mathrm{K}$ & 型 & 420 & $\begin{array}{lll}5 & 1 & 0\end{array}$ & 68 & 9 & 12 & 8 & 52 & 72 & 480 \\
\hline I & 型 & 380 & $\begin{array}{lll}5 & 0 & 0\end{array}$ & 75 & 12 & 9 & 3 & 42 & 54 & 460 \\
\hline Y & 型 & 420 & 650 & 72 & 10 & 9 & 3 & 49 & 61 & 500 \\
\hline M & 型 & 407 & 481 & 68 & 12 & 12 & 8 & 52 & 72 & 470 \\
\hline $\mathrm{O}$ & 型 & 424 & 480 & 68 & 10 & 12 & 4 & 52 & 68 & 470 \\
\hline
\end{tabular}

用いた。推定風量は $0.8 \mathrm{~m}^{3} / \mathrm{sec}$ - $100 \mathrm{~kg}$ で, 毎時乾減速度は 約 $0.3 \%$ あった。

5 ）調査方法

(1) 発芽率：調査粐 50 粒を ンャーレで 3 連制に, 処理温度 は $300{ }^{\circ}$ C゙置床後 7 日めに調查 した。発芽基準は芽長 10 ma 上で根が 1 本以上出ているすの
はホウネンワセ(早生)を供試した。収穫時の供試 材料は第 1 表と第 2 表に示した。高水分粐を得るた め出穂後 30 日前後の早期飞試験を行った。したが って黄化粐の割合が $80 \%$ 末満で, 青米が $18 \%$ 余 り混入し, 粐含水率は $28.8 \%$ でった。

種粐収穫時の作業性能之損傷粐の発生要因に関し ては日本晴（晚生）を用いた。作物の概要は第 3 表 に示したが, 本年度（１９９７６年）の晚生種は低温 と日照不足のため出穂期, 成熟期ともに平年より 1 週間余り遅れた。

\section{2 ）供試機種}

供試機は現在市販されている 2 条刈り自脱型コン バイン 5 機種を用いた。供試機種の脱穀部の仕様は 第 4 表に示した。I 型は上扱ざ方式で他の 4 機種は 下扱き方式である。

\section{3 ）試験区構成}

(1) 刈取時期と品種: 出穂後日数, $30 \sim 33$

日, ホウネンワセ, $42 \sim 44$ 日, 日本晴。

(2) 粐含水率: $28 \sim 30 \%$

(3) 扱胢回転数比率： $80,90,100,110 \%$ ただし回転数比率は機種毎のイネの扱胴標 準回転数を基準にした。

(4) 刈取速度: $0.4 \sim 0.7 \mathrm{~m} / \mathrm{sec}$.

(5) 試験項目

(1) 機種別の粐の損傷率と発芽力

(1) 低回転数比率における作業性能

(D) 2 番還元の有無と損傷率

(1) 受網目の大をさと損傷率

6) 調査項目: 発芽率, 損傷率, 選別精度

4 ）乾燥方法

試験区の構成にしたがって収穕した粐を規定含水 率 $15 \%$ をで乾かすのに, 静置型常温通風乾燥機を
を完全発芽とし，供試粒数に対する割合で示した。

（2）損傷率：乾燥した粐 300 粒を手で脱ぷし, その玄米を水に 30 分浸して水を切り, ヨード, ヨ 一ドカリ液に 30 分間浸漬後, 肧乳部飞受けた傷を 染色し $1.0 \mathrm{~m} \times 1.0 \mathrm{~m}$ 以上の大染色斑が認められた るのを損傷粒とした。ただしヨード、ヨードカリ液 は水 100 c.cに対してヨーソ0.05g, ヨウ化カリ ウム $1.5 \mathrm{~g}$ を溶解したるのを用いた。

(3) 粐含水率：生脱穀中飞 1 番口上 b, 穀粒約 10 $g$ を科量缶飞取 り, 通風恒温乾燥法 ( 1050 c - 24 $\mathrm{hr}$ 法)で乾燥し, 3 点平均の湿量基準で示した。

\section{3. 結果および考察}

1) 機㮔別における粐の損傷率および発芽率と選 別精度

（1）機種別にょる回転数比率と損傷率および発芽 率

第 1 報で述へたように，機種別の損傷粐の発生は 扱胴の周速度で比較した場合, 機種間差が認められ た。そこで本報では市販されている则巾７５０ｍの 2 条刚り自脱型コンパイン 5 機種につんて, 各機種 の標準回転数を基準に扱胴回転数比率 80,90 ,

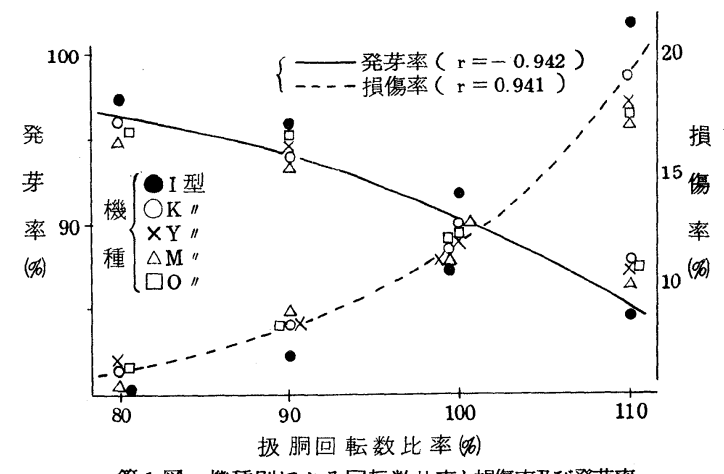

第 1 困 機種別による回転数比率と損傷率及び発芽率. 
$100,110 \%$ 段階で, 粐の損傷率および発 芽率の機種間差を調查した。その結果が第 1 図の通 りである。

機種間の損傷率は回転数比率 $80 \%$ 亿抏いて4.3〜 6. $3 \%, 90 \%$ で $6.6 \sim 8.7 \%, 100 \%$ では 1 $0.3 \sim 11.7 \%$ にった。乙のよ5に標準回転数 以下では機種間による差が $2 \%$ 以内で小さな値であ った。標準回転数より $10 \%$ 高めると損傷率は 17.0 〜 $21.7 \%$ でその差が，4.7\%に開いた。てのよう にメーカーが標準回転数を決めているのは, てれ以 上に回転数を上げると料の損失量の増加, とくに脱 稃米の発生量が顕著になるからである。しかし自脱 型コンパインで稲を収穕する際, 標準回転数で収穫 するよらに指導が徹底されているため，それ以下で 収穫する場合，機種間の差は小さく，湆とんどない あのと判断された。とのときの扱胴回転数比率と損 傷率との間の相関係数は $\mathrm{r}=0.941$ で相関々係は高 かった。

一方, 発芽率は損傷率とは逆儿負の相関々係で, $r=-0.942$ であった。回転数比率 $80 \%$ におい て, 各機種間の発芽率は $95.0 \sim 97.3 \%$ で機種間 差が $2.3 \%$ 以内であった。また，回転数比率 $90 \%$ では $93.3 \sim 96.0 \%, 100 \%$ では $89.0 〜 92.0$ \%, $110 \%$ では 84.7 〜 $8.0 \%$ 亿なり, 回転数 比率が低くなるほど機種間差が損傷率と同様に小さ くなった。

以上のととから機種間による発芽率の差異壮標準 回転数以下では $3 \%$ 以内にとどまり，農産物規格規 定の水稻種子の発芽率の最低許容限界は $90 \%$ で るが，機種間差を考慮して発芽率 $95 \%$ 以上を確保 するためには，第 1 図から回転数比率で約 $85 \%$, つまり各機種の扱胴標準回転数より $15 \%$ 減じた回 転数で収穫すれば良いととが推察される。をた， のとをの粐の損

傷率は約 $7 \%$ 以 以下に抑えられる。 このととは高水 分粐 $(28.8 \%)$ の䈌しい条件下 で行ったもので あるが，収穫適 る。 傷が㹸とんどである。 第 5 表 穀粒流量と粐の損傷及び発芽率

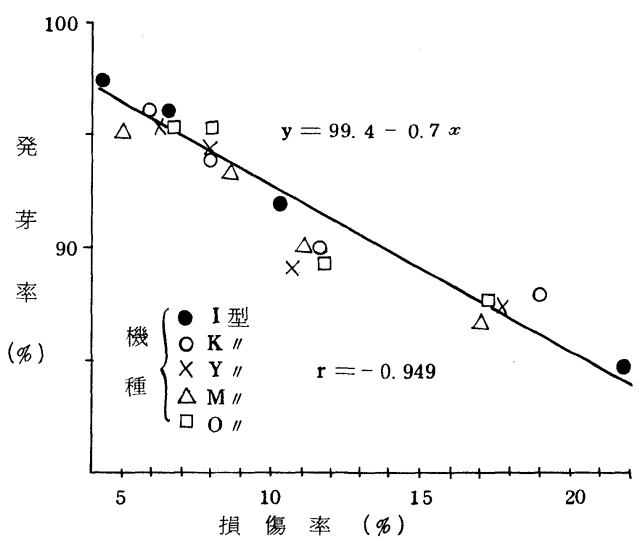

第 2 図機種別に上る損傷率と発芽率

期になるをでには粐水分が低下するので， $15 \%$ 減 の回転数で収穫すれば発芽率はより確実に向上す

(2) 機種別による損傷率と発芽率の関係 粐の損傷率と発芽率の関係は第 1 報で述べたよら 飞, 粐含水率別にみてみると相関々係が非常に高か った。本報は機種間による損傷率が発芽率にどのよ らな関係があるかをみたのが第 2 図である。

その結果，機種間による差は汪とんどなく，相関 係数 $\mathrm{r}=-0.949$ で損傷率と発芽率との間には高い 相関々係が認められた。そてで, 損傷率を $\mathrm{X}$, 発芽 率をYにして回帰式：Y=99.4-0.7 X を求めた。 この式より発芽率 $95 \%$ を確保するためにはX=6.3 となり，先に述べたょらに損傷率は約 $7 \%$ 以下にと

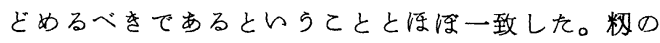
損傷の大きな発生原因は脱穀時に扱菌で粐を脱粒す るときの打撃，そして脱粒された粐が扱室内面に飛 散し衝突して受ける傷, またスローワー部で受ける

そこで粐の損傷を少なくするためには今をで述べ てをたよらに扱胴回転数の低下はすちろんのてと，

\begin{tabular}{|c|c|c|c|c|c|c|c|c|c|c|}
\hline 機 種 & \multicolumn{2}{|c|}{ I 型 } & \multicolumn{2}{|c|}{$\mathrm{K}$ 型 } & \multicolumn{2}{|c|}{ Y 型 } & \multicolumn{2}{|c|}{ M 型 } & \multicolumn{2}{|c|}{ O 型 } \\
\hline 粐 含 水 率 (\%) & \multicolumn{2}{|c|}{28.2} & \multicolumn{2}{|c|}{29.1} & \multicolumn{2}{|c|}{28.7} & \multicolumn{2}{|c|}{29.4} & \multicolumn{2}{|c|}{28.9} \\
\hline 回 転 数 比 (\%) & \multicolumn{2}{|c|}{90} & \multicolumn{2}{|c|}{90} & \multicolumn{2}{|c|}{90} & \multicolumn{2}{|c|}{90} & \multicolumn{2}{|c|}{90} \\
\hline 扱胴回転数 $(\mathrm{r} \mathrm{pm})$ & \multicolumn{2}{|c|}{$\begin{array}{lll}4 & 1 & 4\end{array}$} & \multicolumn{2}{|c|}{432} & \multicolumn{2}{|c|}{450} & \multicolumn{2}{|c|}{423} & \multicolumn{2}{|c|}{423} \\
\hline 刘取速度 $(\mathrm{m} / \mathrm{s})$ & \multicolumn{2}{|c|}{0.38} & \multicolumn{2}{|c|}{0.41} & \multicolumn{2}{|c|}{0.47} & \multicolumn{2}{|c|}{0.37} & \multicolumn{2}{|c|}{0.58} \\
\hline 穀粒流量 & 420 & 220 & 470 & 220 & 540 & 250 & 540 & 250 & 600 & 260 \\
\hline 損 傷 率 (\%) & 6.6 & 9.3 & 8.0 & 10.0 & 8. 0 & 9.7 & 8.7 & 10.6 & 8.0 & 9.0 \\
\hline 発＼cjkstart芽 & 96.0 & 93.3 & 94.0 & 92.7 & 94.3 & 92.3 & 93.3 & 92.7 & 95.3 & 93.3 \\
\hline
\end{tabular}


扱窒内面や扱歯にクッション材を使用して傷害 防止に役立てるてとも考えられる。

(3) 款粒流量と粐の損傷率および発芽率

款粒流量は 2 条刚りと 1 条刚りを行って流量 に差をつけた。機種間により流量は異なるが, 2 条刚りでは $420 \sim 600 \mathrm{~kg} / \mathrm{h}, 1$ 条㺫りでは 2 条刚りの約半分であった。をた。機種の扱胴回 転数比 90 を一定にして損傷率と発芽率の関係 を調査した。その結果は第 5 表の通りである。

各機種とも穀粒流量が少なくなると損傷率は 増加した。穀粒流量が多い場合には。機種間の 損傷率は $6.6 \sim 8.7 \%$, 少ない場合には 9.0 10.6 \%で約 $2 \%$ 余増加した。この上らに穀粒流量の 多少による損傷率の増加は標準回転数以下では 小さかった。しかし流量が増加すると損傷率が やや低下するのは，穀粒流量が増加するととに よって，扱室内で穀粒間の干涉があり，粐間の 衝撃力が弱まるためと考えられる。

しかし、このととは発芽率にもわずかに影響 し, 穀粒流量が少ないと発芽率は約 $1 \sim 3 \%$ 低 下した。第 1 報で述べたょうに回転数を低下さ せる任ど穀粒流量の多少が粐の損傷率および発 芽率への影響は小さくなる。乙のととから回転 数比率を $85 \%$ 亿すると発芽率の低下は，また 一段と小さくなるととが推察される。しかし穀 粒流量坆別精度や異常粐の発生等も考慮して, 不足ざみより適流量で収穫したほうがより発 芽率の向上につながる。

（4）機種別による選別精度と異常椟の発生

機種別による穂切れ粒と枝梗付着粒の発生率は, 第 3 図にみられるよ5に, 回転数の増加とともに減 少した。しかし脱ぷ粒の発生は回転数の増加に伴な ってわずかであるが, 発生し, 標準回転数以上にな ると急増する。生種間による差は標準回転数以 下ではI型はやや多く，Y型はわずかに少ない傾向 であった。一般的な特長として上扱ぎ方式は下扱ざ 方式ょりる枝梗付着粒と穂切れ粒および脱ぷ粒の発 生がやや多いといらとととほ医一致した。しかし上 扱ぎ式は脱穀実所要動力が下扱ぎ方式よりも少な くてすみ, 脱穀能率の向上につながるという特長を もっている。

このように選別精度は機種間において差が認めら れるが, 各機種とも高水分粐で糐切れ，枝梗付着粒 の合計值が $10 \%$ 以下であったので, 循環型乾燥機 にかけても運転上支障がないものと考えられる。

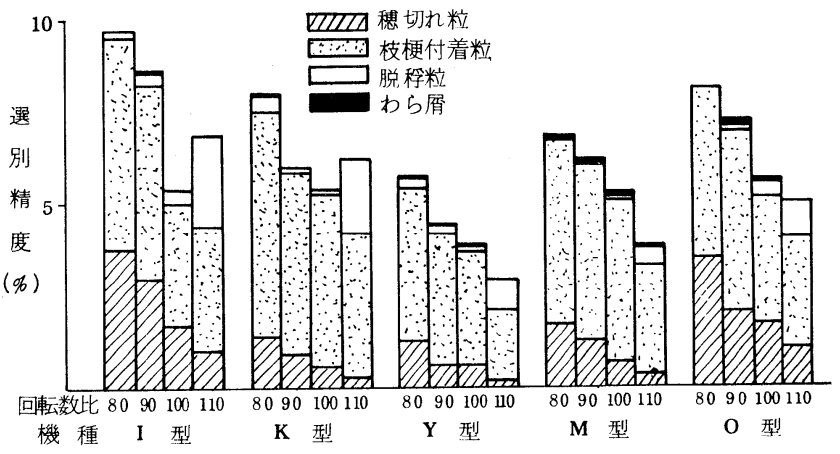

第 3 図機種別による選別精度

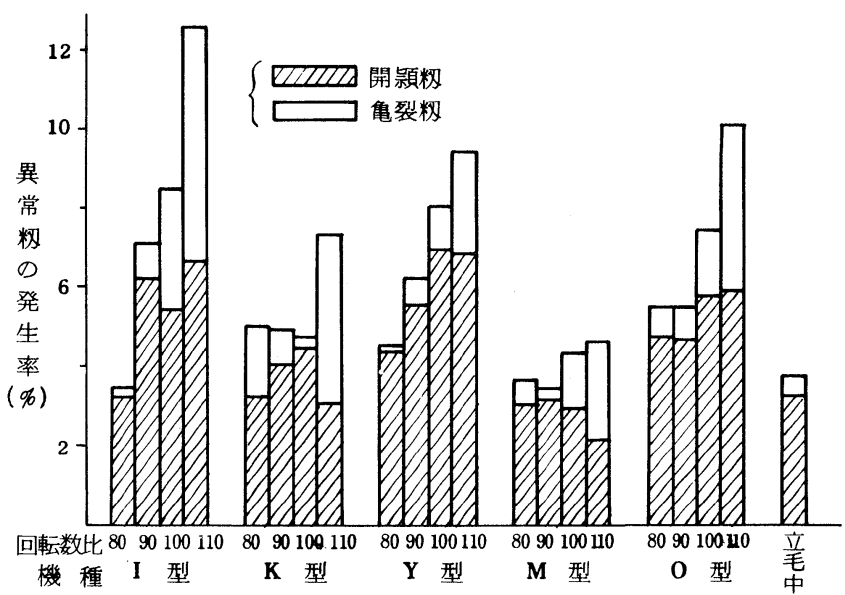

第 4 図 機種別による異常粐の発生

また第 4 図にみられるよらに, 異常粐(開頴粐十 亀裂粐) は選別精度とは反比例して, 回転数が増加 する汪ど発生率は高主り，概して影の結合部以外の 部位で裂皮する重裂粐の増加率が大きい。

機種別にみると $\mathrm{M}$ 型は生脱穀しても異常粐の発生 率は立毛中のものと活とんど变らなかった。とてで も上扱ぎ方式のI 型は異常粐の発生率が他の下扱ぎ 方式の 4 機種よりもやや高い傾向がみられる。Y， $\mathrm{O}$ 型壮次いで多く，そしてK型の順で $\mathrm{M}$ 型は最も少 なかった。

このよらに異常粐の発生に関し, 機種間に差がみ られた。しかし回転数比率 $80 \%$ です異常粐の発生 が $5 \%$ 前後でかなり多く発生した。乙れは立毛中に おける発生率が約 4 \% 近くみられるように粐割れの しやすい品種であったととが影響している。

2) 種粐収穫による作業性能と損傷籾の発生要因

（1）扱胴の回転数低下時における作業性能

日本晴の高水分粐を收穫時に扱胴回転数を標準回 
第 6 表 扱胴の回転数低下時における作業性能

\begin{tabular}{|c|c|c|c|c|c|c|c|c|c|c|c|c|}
\hline 機 & \multicolumn{3}{|c|}{ I } & \multicolumn{3}{|l|}{ 型 } & \multicolumn{3}{|c|}{$\mathrm{K}$} & \multicolumn{2}{|l|}{ 型 } & \\
\hline 穀 流 粒 量 $(\mathrm{Kg} / \mathrm{h})$ & 647 & 684 & 792 & 697 & 792 & 936 & 510 & 550 & & 540 & 576 & 648 \\
\hline 負荷時回転数 $(\mathrm{r} \mathrm{pm})$ & 345 & 338 & 332 & 400 & 395 & 390 & 365 & 355 & $\begin{array}{l}\text { 番主 } \\
\end{array}$ & 390 & 380 & 370 \\
\hline 有効作業量 $(\mathrm{a} / \mathrm{h})$ & 7.1 & 8.4 & 10.6 & 7.6 & 9.3 & 12.8 & 6.0 & 6.9 & ワる & 6.7 & 8.0 & 9.5 \\
\hline 損 傷 率 (\%) & 3.4 & 2.3 & 3.3 & 6.3 & 5.3 & 5,7 & 3.0 & 2.7 & 1 & 7.0 & 4.7 & 5.3 \\
\hline 発 芽 率 $(\%)$ & 97.3 & 98.7 & 98.0 & 98.0 & 98.0 & 98.7 & 97.3 & 97.3 & & 98.7 & 96.7 & 95.3 \\
\hline
\end{tabular}

注 1 ) 粐水分 $28.9 \%$, 茥葉水分 $75.4 \%$

第 7 表 2 番還元の有無と損傷率, 発芽率及び選別精度

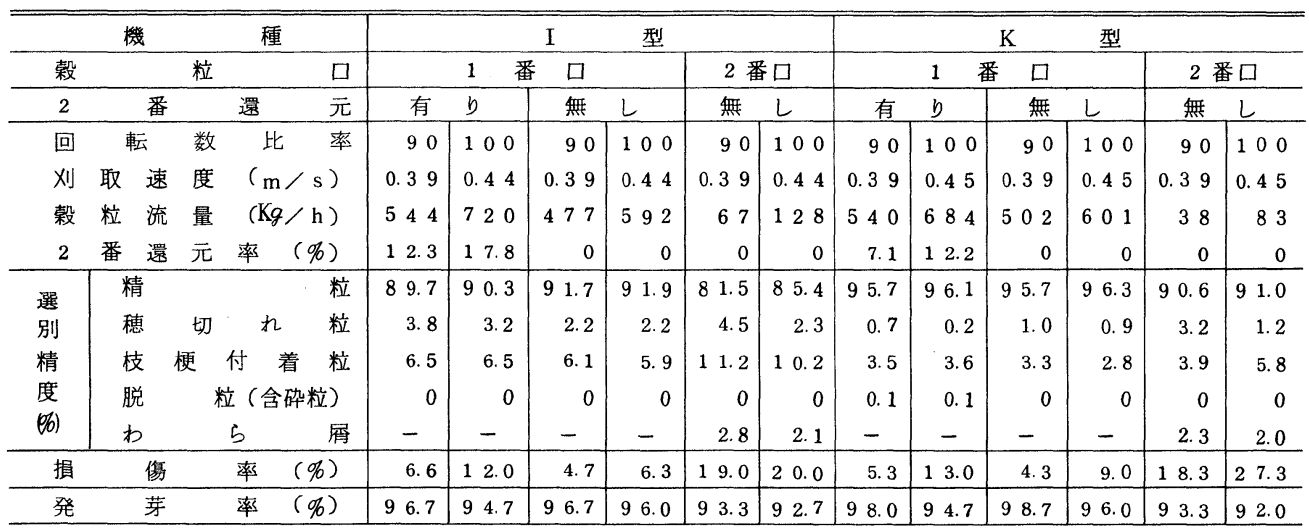

注 1 ) 粐水分 $24.9 \%$, 茥葉水分 $70.2 \%$

転数より 15 \% 低下させた場合, 作業性能にどのよ らな影響を及ぼすかについて検討した。その結果は 第 6 表に示した。

自脱型コンバインI 型は回転数を $20 \%$ おび 10 \%低下させて 2 条刚りした場合, 则取速度を0.33 〜 $0.57 \mathrm{~m} / \mathrm{s}$ の範囲内では正常に稼動した。そのと きの無負荷時の回転数比率 $80 \%$ では負荷時には穀粒 流量が多くなるにつれて，回転数が $6.2 \%$ から 9.8 \%まで低下した。回転数比率が上って $90 \%$ になる と $3.4 \%$ から $5.8 \%$ を゙低下し, 回転数比 $80 \%$ よ りあ回転数の低下率は小さかった。

また $\mathrm{K}$ 型では回転数を $20 \%$ 低下させて 4 速で収 穫したととろ，2 番スローワに詰まりが生じた。し かし $15 \%$ 低下では機械的な異常はみられなかった。 このとをの回転数低下率は $4.4 \%$ から $9.3 \%$ あっ た。

また作業能率は有効刘取巾を $0.6 \mathrm{~m}$ として有効作
業量を求めると, 回転数比率 $85 \%$ な゙ $0.4 \mathrm{~m} / \mathrm{s} の$ 速度で収穫すると 1 時間当り約 $8.6 \mathrm{a}$ にな b, 圑場 作業効率を $70 \%$ 規定した場合には固場作業量は 1 時間当り約 6 a の能率となった。とのとをの損甥率 は7\%以下で，機種間の差はほとんとなく発芽率も すぺて95\%以上確保でをた。このよらに回転数を15 \%低下させて 2 番スローワ部および脱穀部内に詰ま り現象が生じない程度で収穕すればよいすのと考え られる。

（2） 2 番還元の有無が損傷率および発芽率と選別 精度に与える影響につんて

収穫時の扱胴回転数は標準回転数とそれより 10 $\%$ 低ら回転数で行った。その結果は第 7 表の通りで ある。

I 型の 2 番還元率は回転数比率 $90 \%$ で $12.3 \%$, $100 \%$ で $17.8 \%$ であった。K型は回転数比率90 \%で $7.1 \%, 100 \%$ $102.2 \%$ とり, 回転数と穀 
粒流量が増加するにつれて 2 番還元率す上 昇した。このよらに機種間による差はやや 認められるが, 回転数比率を $85 \%$ 亿低下 させると 2 番還元率は $10 \%$ 以下になるだ ろらと推察される。

損傷率は 2 番ロで取り出したすのが二番 スローワの羽根の衝撃も加算されて約 20 $\%$ 発生した。回転数比率 $85 \%$ の場合，2 番 還元率が $10 \%$ 以下であれば，理論的には 還元するものは，還元しないるのより $2 \%$ 以下 の範囲内で損傷率は增加する。第 7 表加ら あみられるよらに回転数比率 $90 \%$ で 2 番 還元のあるものはないるのよりる損傷率は1.0〜2.0 \%増加し, 5. 3 6.6\%の発生率であった。 このように損傷率は 2 番還元の有無によりわずかに 増加したが， 7 \%以下であるため発芽率は $96 \%$ 以 上で死とんど差がなかった。回転数比率100\%で2 番還元すると損傷率壮 $4 \sim 6 \%$ 増加し, $12 \sim 13$ の発生率であった。そのとをの発芽率は $94.7 \%$ で $1.7 \%$ 低下した。回転数比が高くなるにつれ，2 番 還元の有無が損傷率および発芽率に影響してくる。 しかし回転数比率 $85 \%$ では 2 番還元の有無が損傷 率に及はす影響は小さく，発芽率にす殆んど差が認 められなかった。てのてとから回転数を $15 \%$ 减ず れば 2 番還元しても損傷率の増加は小さく, 無視す るととができる。

一方，I 型機の選別精度は穂切れ，枝梗付着粒の 合計値が 2 番還元有りが約 $10 \%$, 無しが約 $8 \%$, $\mathrm{K}$ 型機では還元の有無に湆とんと関係なく，約 $4 \%$ の発生率で, 機種間には若干差が認められた。

(3)受網目の大ささが損傷率および発芽率と選別 精度に与える影響について

受網目の大ささは 9, 12,15 mam 3 段階に変え, 粐の損傷，発芽および選別精度を調查した結果を第 8 表に示した。また穀粒流量，刚取速度は 2 番還元 の試験項目に準じた。

料の損傷率は回転数比率 $90 \%$ で受網目の大を さによる差が $1.2 \%$ ほほとんど影響しなかった。し かし回転数を上げ回転数比率100\%では受網目の大き さによる影響がみられ，9 ma地区損傷率が最も高く $12 \%, 12$ ma 区 $9 \%, 15$ ma 区は $10 \%$ そ, そ
第 8 表 受網目の大きさと損傷率, 発芽率および選別精度

目の内寸 $(m)$

\begin{tabular}{|r|r|r|r|r|r|r}
\hline \multicolumn{9}{|c|}{ I } & \multicolumn{1}{|c}{$12 \times 12$} & \multicolumn{2}{|c}{$15 \times 15$} \\
\hline & \multicolumn{2}{|c|}{$9 \times 9$} & \multicolumn{1}{|c}{ 型 } \\
\hline & 90 & 100 & 90 & 100 & 90 & 100 \\
\hline
\end{tabular}

1) 粐水分 $28.8 \%$, 茎葉水分 $70.3 \%$

の差が $3 \%$ あった。

このととは発芽率にも影響し, 回転数比率 $90 \%$

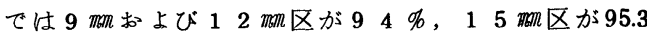
\%で压とんど差はみられないが, 回転数比率が 100 \%になると損傷率の最も高い 9 即区の発芽率の低下 が大をく $90 \%$ になった。しかし 12 m小よび 15 m区日 $93.3 \%$ で発芽率の低下は小さかった。ての よらに受網目の目合いが大をくなるほど, 受網から の濾過が早く，粐の損傷はまぬがれやすい。

しかし, 標準回転数より15\%低下させた場合に は，受網目の大をさの相違による損傷率の差すます ます小さくなり発芽率への影響は少ないるのと考え られる。

また選別精度の穂切れ，枝梗付着粒は受網目の大 ささが大をくなるほど, 多く発生し15 m 転数比率 $90 \%$ で両者合わせて $10 \%$ 以上発生した。 開影粐，亀裂粐の異常粐の発生は垂井 ${ }^{4 ）}$ 。述へて らるように，開穎粐は扱胴の回転数が上昇してもそ れ医ど増加しないが，亀裂粐の増加は大きかった。 そして受網目の小さい 9 m区が他の 12 m小おび 15 m的区よりすやや多く発生した。

すなわち選別精度, 異常粐の発生は生粐が扱室内 に滞留する時間に影響される。しかし損傷率は標準 回転数より15\%低下では，受網目の大ささによる 差は小さく発芽率に质とんど影響しないが, 選別精 度と異常粐の発生率からみて受網目の大きさは 12 Ma矿区適当であった。

4. 要 約 
水稻種子生産の機械化をはかるため, 本報では自 脱型コンバインの機種による差が, 粐の損傷と発芽 率にどのよらに影響し，そのときの作業性能と損傷 粐の発生要因について検討した。

(1) 自脱型コンバインの損傷率は標準回転数を基 準に, それ以下で収穫した場合，機種間の差は小さ く発芽率への影響も少なかった。

種粐としての発芽率の安全性を考慮して, 発芽率 $95 \%$ 確保するためには扱胴回転数を機種の標準回 転数より $15 \%$ 減が適正回転数で, 損傷率 $7 \%$ 以下 に抑えるととが肝要である。

(2) 穀粒流量の不足は標準回転数以下ではわずか に損傷粐の発生を促し，発芽率の低下ををたす。ま た選別精度は機種間に若干の差がみられるが, 高水 分粐で穂切れ粒と枝梗付着粒の合計值が $10 \%$ 以下 であれば循環型乾燥機の運転上, 支障はきたさない。 (3) 扱胴の回転数を標準から $15 \%$ 減で， 2 番ス ローワ部等に詰まり現象が生じない程度の速度で収 穫すればよく, そのとさの固場作業量は普通収穫時 上りซ $20 \sim 30 \%$ 低下する。
（4）たた前述の条件で収穫すれば，2番還元およ び受網目の大をさは損傷粒の発生および発芽率の低 下には影響が少ない。

\section{5. 摘 要}

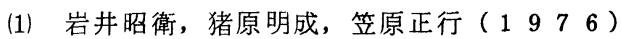
水稲種子生産の収穫調製機械化技術体系飞関する研 究。第 1 報 自脱型コンバインによる粐の損傷と発 芽率について, 農作業研究, 第 27 号, P $14 \sim$ 20

（2）小林一, 三輪精博, 伊藤正人, $\left(\begin{array}{llll}1 & 9 & 7 & 6\end{array}\right)$ ビ ール麦における吸収力積と傷の関係農業機械学会 関西支部報, 第 39 号, P $35 \sim 39$

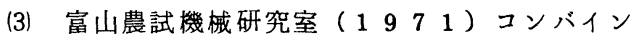
収穫粐の選別程度が乾燥調製機の性能に及ほす影響 に関する試験, 農業機械試験研究成績書, 第 11 号, P $137 \sim \sim 150$

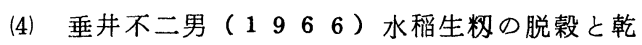
燥飞関する実験的研究, 福井農試特別報告, 第 2 号, P $22 \sim 26$ 